Edunomika - Vol. 03, No. 02 (Agustus 2019)

\title{
PENGARUH HARGA, KERAGAMAN PRODUK DAN MEREK TERHADAP KEPUTUSAN PEMBELIAN PRODUK PADA PT. INDEX SUKOHARJO
}

\author{
Manab Semarang, Sri Hartono, Burhanudin AY \\ Fakultas Ekonomi, Universitas Islam Batik Surakarta \\ Email: naffasd@gmail.com,
}

\begin{abstract}
The purpose is to know the effect off prices, product diversity and brands on product purchasing decisions at PT. Index Sukoharjo both simultan and partially. This research was conducted with a quantitative approach, collection data was done by distributing question naires and documentation. The sample used was 85 people. The analytical tool used is test data instruments, classic assumption tests and multiple linear regression. The results and have been found and proven that all research data include valid and realiable categories, so that the research data is feasible to continue in the subsequent data analysis process. The results of the hypothesis testing of this study using econometric tests in the form of multiple linear regression (multiple regression) obtained the equation: $Y=-0.587+0.350 X 1+0.380 X 2+0.315 X 3$. Product diversity is the most dominant variable in influencing customer purchasing decisions on furniture products of PT. Index Sukoharjo. In the determination of price variables, product diversity, brands have an influence on product purchasing decisions by 66\%. PT. Index needs to look for other factors that may also increase customer purchasing decisions on the furniture products offered. Based on the results of data analysis it is known that together $\underline{\text { and }}$ individually the price variable, product diversity, discipline and brand have a significant effect on the customer purchasing decisions of PT. Index Sukoharjo.
\end{abstract}

Keywords: Brand, Price, Product Diversity, Purchasing Decision

\section{PENDAHULUAN}

Perkembangan industri mebel di Indonesia sangatlah pesat, hal ini dikarenakan permintaan dan kebutuhan akan produk mebel, furniture terus meningkat. Salah satu sumber devisa negara saat ini adalah dari produksi mebel karena peminat produk tidak hanya di kalangan domestik saja, namun juga merambah kalangan internasional. Kondisi ini membuat para pengusaha furniture terus berkompetitif guna memproduksi produk yang berkwalitas sesuai dengan keinginan konsumen.

Beberapa perusahaan yang bergerak dalam bidang mebel atau furnitur di Kabupaten Sukoharjo diantaranya PT. Swastama, PT. Salute Furniture, PT. Wirasindo Santa Karya, PT. Citra Classic Furniture, terdapat perusahaan mebel furniture terbesar yaitu PT. Index yang merupakan salah satu dari perusahaan furniture yang terus bersaing dengan perusahaan yang sama. Hasil produk furnitur dari PT. Index sudah diakui kualitas maupun nilai seninya oleh pelanggan domestik maupun Internasional. Hasil produksi PT. Index bukan saja di pasar nasional bahkan merambah ke 
luar negeri seperti Amerika Serikat, Inggris, Belanda, dan Prancis. Kualitas produk menjadi point utama dalam yang harus diperhatikan perusahaan, baik pengerjaannya, bahan baku, pengolahan semuanya dilakukan sebaik mungkin agar produk yang dihasilkan berkualitas sehingga pembeli tidak akan kecewa.

Seiring dengan berubahnya perekonomian yang cenderung semakin meningkat maka bertambah juga kebutuhan atau keinginan pelanggan dengan beragam pilihan produk atau barang, merk, harga, dan pemasok. Itulah yang sering disebut perilaku konsumen atau perilaku pelanggan. Perilaku pelanggan yang paling utama adalah dalam hal keputusan membeli, sebelum mengambil keputusan untuk beli suatu produk tentunya akan melakukan beberapa tahapan diantaranya memberikan penilaian terhadap barang yang akan dibeli, manfaat yang ada pada barang tersebut, kemudian harga yang harus dibayarkan untuk barang tersebut. Apabila sudah dinilai cocok dengan kriterianya tersebut, barulah pelanggan akan mengambil keputusan untuik membeli.

Faktor yang berpengaruh pada keputusan pembelian salah satunya adalah price atau harga, banyak pendapat ahli yang mendefinisikan tentang harga, salah satunya adalah Umar (2000: 32) yang menyebutkan bahwa price yaitu sejumlah nilai yang ditukarkan pelanggan dengan suatu produk melalui proses jual beli melalui tawar menawar.

Selain harga, keragaman aneka produk dapat mempengaruhi keputusan pembelian suatu barang. Keragaman aneka barang adalah kelompok suatu barang yang berbeda-beda disajikan pejual ke pebeli (Kotler dan Keller, 2009: 15). Keragaman produk ini dapat berjalan apabila perusahaan inovatif dalam menciptakan produk baru atau variasi pada produk yang sudah dihasilkannya. Semua hal tersebut dilakukan perusahaan untuk meningkatkan pembelian konsumen, karena konsumen cenderung untuk memilih produk yang beranekaragam dan lengkap. Keputusan pembelian suatu produk tidak hanya mengandalkan tersedianya keragaman produk saja tetapi dipengaruhi juga oleh merk. Definisi merk adalah nama/simbol guna membedakan dengan barang perusahaan lain (Aaker, 2010: 125).

Guna memudahkan peneliti dan pemahamannya maka rumusan masalah penelitian ini adalah:

1) Apakah variabel harga, variabel keragaman produk dan variabel merk secara simultant berpengaruh pada keputusan pembelian produk PT. Index Sukoharjo?

2) Apakah harga berpengaruh pada keputusan pembelian produk PT. Index Sukoharjo?

3) Apakah keragaman produk berpengaruh pada keputusan pembelian produk PT. Index Sukoharjo?

4) Apakah merk berpengaruh pada keputusan pembelian produk PT. Index Sukoharjo?

\section{TINJAUAN TEORI}

\section{Keputusan Pembelian}

Proses dimana seseorang harus berpikir, menganalisis dan menilai sebelum memutuskan sesuatu sesuai yang diinginkannya itu disebut keputusan Pendapat Kantohe dan Merlyn (2014: 70) mendefinisikan keputusan pembelian sebagai sutau kegiatan manusia untu 20 penyelesaian masalah 
sebelum pembelian barang jasa. Keputusan membeli menurut Kotler dan Armstrong (2008:181), adalah membeli barang merk yang diinginkan dengan berbagai alternatif yang ada. Proses pengambilan keputusan (Kotler dan Armstrong, 2008:179):

a. Pengenalan masalah, yaitu seseorang sadar pada keinginan sesuai dengan harapan.

b. Pencarian informasi, yaitu cari dan kenali atribut-atribut dari objek yang diinginkan

c. Evaluasi alternatif, yaitu pelajari dan evaluasi alternatif agar dapat alternatif pilihan yang terbaik sebelum memutuskan membeli.

d. Keputusan pembelian, yaitu seseorang mengambil putusan untuk membeli setelah menlakukan evaluasi terhadap barang yang akan dipilihnya.

e. Prilaku pasca pembelian, adalah keadaan pasca membeli suatu produk, pelanggan akan menilai terhadap barang yang sudah dibeli yaitu puas atau tidak puas.

Hsu dan Chang (2008: 247) indikator untuk pengukuran variabel keputusan membeli adalah :

a. Ingin menggunakan produk

b. Ingin membeli produk

c. Memprioritaskan membeli suatu produk

d. Bersedia berkorban untuk mendapatkan suatu produk

\section{Harga}

Arti harga sebagai salah satu siklus pemasaran yang menguntungkan dan biaya sesuai dengan fitur produk dan saluran distribusi (Kotler dan Keller, 2009: 67). Pendapat Alma (2011: 169) mengenai harga sebagai angka rupiah pada barang. Daryanto (2013:62) arti dari harga adalah sejumlah nilai rupiah yang ditagih untuk sebuah barang. Kotler dan Amstrong dikutib Bob Sabran (2008:410) menyebutkan indikator harga adalah: penetapan harga jual, elastisitas harga, dan pertumbuhan harga pesaing.

\section{Keragaman Produk}

Keragaman produk menurut James F. Engels alih bahasa Farli Liwe (2015: 209) keragaman produk yaitu produk yang komplit menyangkut model, ukuran, warna dan kualitas barang yang ditawarkan serta setiap saat tersedia di pasar. Keragaman produk adalah sejumlah kategori barang/produk yang ada di dalam toko. Raharjani dalam Mulyani (2009: 104) menjelaskan bahwa keragaman produk adalah kekomplitan dan ketersediaan produk yang dijual. Konsumen lebih memilih toko yang menawarkan barang secara lengkap dan banyak pilihannya baik merk, type and size, kemasannya, dan lain-lain. Dalam bisnis perdagangan, kelengkapan aneka barang dagangan met3 adi faktor yang utama yang dapat menarik pelanggan, meskipun harganya lebih tinggi dari pasar pesaing, tetapi karena komplitnya produk yang dijual, maka pasar ini lebih banyak menarik para pelanggan. Menurut Kotler (2009: 358) indikator variabel keragaman produk adalah variasi merk, kelengkapan produk, ukuran produk, dan kualitas produk. 


\section{Merk}

Pada dasarnya merk bukan sekedar nama atau simbol, melainkan menjelaskan produk atau layanan tersebut. Merk merupakan cerminan nilai yang diberikan oleh produk maupun perusahaan. Tujuan dari pemberian merk adalah untuk mengetahui cara memberikan kegunaan yang dibutuhkan oleh pelanggan. Merk yang lebih sampaikan akan lebih muda dikenal secara efesien dan efektiv kepada pelanggan (Susanto, 2004 : 10). Menurut Aaker (1991) dalam kutipan Durianto dkk (2011:4) indikator merk antara lain kesadaran suatu merk, asosiasi merk, persepsi seseorang terhadap kualitas merk, dan loyal terhadap suatu merk. Skema kerangka pikir sebagai berikut:

\section{METODOLOGI}

Penelitian ini mengambil lokasi salah satu perusahaan furnitur yang ada di Sukoharjo yaitu PT. INDEX, tepatnya Jl. Arak-arak No. 54 Telukan, Grogol, Sukoharjo. Pertimbangan pemilihan ini adalah PT. INDEX memiliki cukup banyak data yang peneliti perlukan dan mendapatkan ijin untuk mengumpulkan data penelitian. Populasi yang diamati adalah pelanggan PT. Index Sukoharjo yang berjumlah 512 dan jumlah sampel 85 pelanggan yang semuanya bersedia memberikan informasi yang dibutuhkan terkait dengan penelitian ini. Sampel diambil secara insindental, yaitu secara kebetulan, dalam arti saat melakukan penyebaran kuesioner setiap ketemu mahasiswi Fakultas Ekonomi UNIBA Surakarta dijadikan sampel, bila mahasiswi yang kebetulan ditemui berkenan sebagai responden. Metode pengumpulan data dengan dokumentasi dan angket. Teknik analisis data dengan uji Regresi Linier Berganda.

\section{ANALISIS DATA DAN PEMBAHASAN}

1) Uji F

Hasil Olah Data, 2019, diketahui besarnya Fhitung = 55,430 > Ftabel 2,68 dengan Signifikansi $0,000<a=0,05$ yang berarti harga, keragaman produk dan merk secara bersama-sama memiliki pengaruh yang signifikan pada keputusan pembelian produk oleh pelanggan dari perusahaan PT. Index di Sukoharjo.

\section{2) Uji t}

Berdasarkan hasil pengolahan data dapat disajikan hasil Uji t sebagai berikut :

a. Terbukti variabel harga memiliki pengaruh signifikan pada keputusan pembelian furnitur4 PT. Index di Sukoharjo (thitung = 4,448 > t tabel 1,980).

b. Terbukti variabel keragaman produk memiliki pengaruh signifikan pada keputusan pembelian furniture PT. Index di Sukoharjo (thitung $=5,187>\mathrm{t}$ tabel 1,980).

c. Terbukti variabel merk memiliki pengaruh signifikan pada keputusan pembelian furniture PT. Index di Sukoharjo. 


\section{3) Uji Ketepatan Model dengan Koefisien Determinasi $\left(\mathbf{R}^{2}\right)$}

Nilai adjusted $\mathrm{R}^{2}=0,660$ berarti variabilitas variabel keputusan pembelian furniture PT. Index di Sukoharjo dijelaskan oleh harga, keragaman produk dan merk sebesar $66 \%$, sedangkan sisanya dijelaskan variabel lain yang tidak dianalisis seperti faktor lokasi perusahaan, mutu dan kualitas bahan bakunya, sistem distribusinya, dan lain sebagainya.

\section{PEMBAHASAN}

\section{Pengaruh Harga, Keragaman Produk dan Merk Secara Bersama-Sama Terhadap Keputusan Pembelian Produk Pada PT. Index Sukoharjo}

Berdasarkan hasil analisis data diketahui secara simultant variabel harga, keragaman produk, disiplin dan merk memiliki pengaruh signifikan pada keputusan pembelian pelanggan PT. Index di Sukoharjo. Hal ini dibuktikan dengan perolehan $\mathrm{F}$ hitung $=55,430>$ Ftabel $=2,68$ dengan signifikansi $0,000<a=0,00$. Penggabungan secara bersama-sama atau simultan ini ternyata memberikan dampak atau pengaruh signifikan terhadap keputusan pembelian pelanggan pada furniture product PT. Index Sukoharjo. Semakin harga terjangkau, keragaman produk semakin lengkap, dan merk produk yang dikenal bahkan bertaraf internasional maka akan meyakinkan pelanggan untuk memutuskan membeli prduk furnitur PT. Index Sukoharjo. Hipotesis pertama: "Harga, keragaman produk dan merk berpengaruh signifikan pada keputusan pembelian produk pada PT. Index Sukoharjo" teruji kebenarannya.

Hasil penelitian ini sesuai dengan penelitian yang dilakukan oleh Liwe (2013), Heny (2014), Fadmawati (2014), Setianingsih (1516) dan Amron (2018) membuktikan secara simultan persepsi tentang harga, keragaman produk, dan suasana toko memiliki pengaruh bersamaan pada keputusan pembelian konsunin. Dapat disimpulkan bahwa penggabungan secara simultant variable harga, keragaman produk dan merk berpengaruh terhadap keputusan pembelian furniture product PT. Index di Sukoharjo.

\section{Pengaruh Harga terhadap Keputusan Pembelian Produk pada PT. Index Sukoharjo}

Diketahui bahwa secara parsial harga berpengaruh pada keputusan pembelian furniture product PT. Index di Sukoharjo secara significant. Hal ini dibuktikan dengan perolehan thitung = $4,448>$ ttabel $=1,980$. Berdasarkan hasil kuesioner hampir seluruh subjek penelitian menyatakan sangat setuju dan setuju mengenai penetapan harga furniture product yang dihasilkan PT. Index terjangkau untuk semua kalangan domestik, kebijakan penetapan harga berdasarkan kualitas produk, harga yang dipasang sangat bersaing dengan perusahaan furniture lainnya di Sukoharjo. Hipotesis kedua : "Harga berpengaruh signifikan terhadap keputusan pembelian produk pada PT. Index Sukoharjo" teruji kebenarannya. Hal ini sesuai dengan hasil penelitian terdahulu Amron (2018), Novansa (2017), Sucipto (2017), Gian 22 (2016), Fadmawati (2016) dibuktikan harga memiliki pengaruh pada keputusan pembelian. Dapat disimpulkan bahwa harga berdampak secara signifikan pada Keputusan pembelian furniture product PT. Index di Sukoharjo. 


\section{Pengaruh Keragaman Produk Terhadap Keputusan Pembelian Produk Pada PT. Index di Sukoharjo}

Secara parsial keragaman produk memiliki pengaruh secara signifikan pada keputusan pembelian pelanggan PT. Index di Sukoharjo. Hal ini dibuktikan dengan perolehan thitung = 5,187 lebih besar ttabel $=1,980$ dengan signifikansi lebih kecil dari a $=0,05$. Besarnya pengaruh keragaman produk pada keputusan pembelian produk masuk dalam peringkat pertama, karena nilai t hitung lebih tinggi dibandingkan dengan variabel lainnya. Banyak pelanggan menentukan pilihan furniture product PT Index karena salah satunya adalah kelengkapan keragaman produk yang diproduksi dengan berbagai model dan ukuran, sehingga pelanggan yang datang dipastikan pulang membawa produk yang 2 inginkan tanpa mengecewakan pelanggan. Hipotesis ketiga : "Variabel keragaman produk berpengaruh signifikan terhadap keputusan pembelian produk pada PT. Index di Sukoharjo" teruji kebenarannya. Didukung hasil penelitian terdahulu seperti Sucipto (2017), Setianingsih (2016), dan Giang (2016) telah melakukan perbandingan produk yang terdiri dari 5 pernyataan, yaitu pengemasan dan produk menarik, kualitas produk dan informasi produk secara signifikan mempengaruhi keputusan pembelian konsumen untuk merk KFC daripada merk Lotteria. Dan untuk Pizza Hut, hanya kemasan dan produk menarik secara signifikan mempengaruhi keputusan pembelian konsumen untuk Pizza Hut daripada merk Lotteria. Fadmawati (2014), Heny (2014) dan Liwe (2013) juga membuktikan keragaman produk memiliki da 4 pak signifikan pada keputusan membeli. Kesimpulan yang diambil variable keragaman produk berpengaruh signifikan terhadap keputusan pembelian pelanggan PT. Index di Sukoharjo.

\section{Pengaruh Merek Terhadap Keputusan Pembelian Produk pada PT. Index di Sukoharjo}

Secara parsial merek berdampak signifikan pada keputusan pembelian furniture product PT. Index di Sukoharjo. Hal ini dibuktikan dengan perolehan thitung = 4,352 lebih besar ttabel = 1,980. Dan perolehan dari variabel merk ini menunjukkan pengaruh yang paling rendah dibanding variabel lain dalam mempengaruhi keputusan pembelian pelanggan. Produk yang dihasilkan oleh PT Index memiliki merk Bramble yang sudah terkenal baik di wilayah domestik maupun internasional. Pelanggan begitu melihat suatu produk dengan merk Bramble langsung berpikir, ini adalah produk furnitur yang berkualitas dan bagus. Karena selama pengerjakan produk melalui berbagai produk dengan wuality control yang bagus pula. Hipotesis empat : "Merek berpengaruh signifikan terhadap keputusan pembelian produk pada PT. Index Sukoharjo" teruji kebenarannya.

Hal ini sesuai dengan hasil penelitian terdahulu Amron (224), Novansa (2017), Defriansyah (2016), Giang (2016), dan Liwe (2013) hasil penelitian menunjukkan secara parsial merk berpengaruh signifikan terhadap pengambilan keputusan konsumen. Dapat disimpulkan bahwa variabel merk memiliki pengaruh signifikan pada keputusan pembelian produk pada PT. Index Sukoharjo. 


\section{KESIMPULAN}

Hasil uji instrumen penelitian diperoleh bahwa seluruh data penelitian termasuk kategori valid dan realiabel, sehingga data penelitian layak untuk lanjut dalam proses analisis data selanjutnya. Hasil uji hipotesis penelitian ini yang menggunakan uji ekonometrika dalam bentuk regresi linier berganda (multiple regression) didapatkan persamaan: $\mathrm{Y}=-0,587+0,350 \mathrm{X} 1$ $+0,380 \mathrm{X} 2+0,315 \mathrm{X} 3$.

Keragaman produk merupakan variabel yang tertinggi dalam mempengaruhi keputusan pembelian pelanggan pada furniture product PT. Index di Sukoharjo. Secara determinasi variabel harga, keragaman produk, merk memberikan pengaruh terhadap keputusan pembelian produk sebesar $66 \%$. PT. Index perlu mencari faktor lain yang dimungkinkan dapat juga meningkatkan keputusan pembelian pelanggan pada produk furnitur yang ditawarkan. Berdasarkan hasil analisis data diketahui bahwa secara bersama sama dan secara individu variabel harga, keragaman produk, disiplin dan merk berpengaruh signifikan terhadap keputusan pembelian pelanggan PT. Index di Sukoharjo.

\section{DAFTAR PUSTAKA}

Aksara. Fadmawati, P. Mawar. 2014. "Analisis Pengaruh Harga, Pelayanan, Likasi dan Keragaman Produk terhadap Keputusan Pembelian pada Minimarket Andina”. Naskah Publikasi. Fakultas Ekonomi dan Bisnis UMS. Surakarta

Alma Bachtiar. 2011. Manajemen Pemasaran dan Pemasaran Jasa. Bandung : Penerbit Alfabeta

Ardiana, Titin Eka. 2018. "The Effect Of The Perception Of Service Quality On The Decision Of Purchase In Dawet Jabung Traders In Ponorogo." International Journal of Economics, Business and Accounting Research (IJEBAR) 2.04

Daryanto. 2013. Manajemen Pemasaran: Sari Kuliah. Bandung: Satu Nusa.

Defriansyah, D. 2016. "Pengaruh Citra Merk, Harga dan Kualitas Produk Terhadap Keputusan Pembelian Smartphone Samsung Studi Kasus Mahasiswa Universitas Sriwijaya Indralaya)". JEMBATAN - Jurnal Ilmiah Manajemen Bisnis dan Terapan. Tahun XIII No 2. Pp 89 - 102.

Engels, James dan Roger Blackwell. 2015. Perilaku Konsumen. Jakarta: Binarupa

Giang. 2016. "The Study Of Factors That Influence Consumer Purchasing Decisions Towards Top Three Fast Food Brands Including KFC, PIZZA HUT and LOTTERIA In Hochiminh City, Vietnam". The Graduate School of Bangkok University.

Kotler, Phillip dan Kevin Keller. 2009. Manajemen Pemasaran. Jakarta: PT. Indeks Kelompok Gramedia. 
Liwe Farli. 2013. "Kesadaran Merk, Keragaman Produk dan Kualitas Produk Pengaruhnya terhadap Pengambilan Keputusan Konsumen Membeli di Kentucky Fried Chicken Manado". Jurnal EMBA. Vol. 1 No. 4.

Mulyani, Yuliana. 2009. “Analisis Faktor-faktor Yang Mempengaruhi Loyalitas Pelanggan Pasar Swalayan Dengan Kepuasan Sebagai Variabel Intervening (studi kasus pada swalayan Luwes di Purwodadi)". Excellent, Vol, No.2

Novansa, H. 2017. "Purchase Decision Model: Analysis of Brand Image, Brand Awareness and Price (Case Study SMECO Indonesia SME products)". Saudi Journal of Humanities and Social Sciences. Vol 2 Iss. 8. Pp 621-632.

Schiffman, Leon dan Lezlie Lazar Kanuk. 2008. Consumer Behavior (Perilaku Konsumen) 7th Edition 1 Jakarta: PT. Indeks Company Profile.

Setianingsih, N. Fajar. 2016. "Pengaruh Persepsi Harga, Keragaman Produk, Dan Suasana Toko Terhadap Keputusan Pembelian (Studi pada konsumen Dunkin Donuts Ambarukmo Plaza Yogyakarta)". Skripsi. Tidak dipublikasikan FE UNY.

Sucipto. 2015. "Effect of Completeness of Product, Location and Price on Decision of Purchase on Minimarket in Regional of Tembalang City of Semarang”. Jurnal Ekonomi dan Bisnis. Vol 2 No 4. Pp 1-6. 